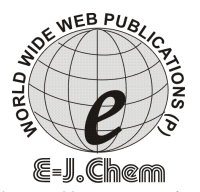

http://www.e-journals.net
ISSN: 0973-4945; CODEN ECJHAO

E-Journal of Chemistry

Vol. 4, No.2, pp 272-278, April 2007

\title{
Adaptation of Color Reactions for Spectrophotometric Determination of Pitavastatin Calcium in Bulk Drugs and in Pharmaceutical Formulations
}

\author{
MAROTHU VAMSI KRISHNA* and DANNANA GOWRI SANKAR \\ Pharmaceutical Analysis and Quality assurance division, \\ College of pharmaceutical Sciences, \\ Andhra University, Visakhapatnam-530003, India.
}

Received 14 November 2006; Accepted 12 December 2006

\begin{abstract}
Three simple, sensitive and cost effective Spectrophotometric methods are described for the determination of pitavastatin calcium (PST) in bulk drugs and in pharmaceutical formulations. These methods are based on the oxidation of PST by ferric chloride in presence of $o$-phenanthroline (Method A) or 2, 2' bipyridyl (Method B) or potassium ferricyanide (Method C). The colored complex formed was measured at 510, 530 and $755 \mathrm{~nm}$ for method A, B and C respectively against the reagent blank prepared in the same manner. The optimum experimental parameters for the color production are selected. Beer's law is valid with in a concentration range of $4-20 \mu \mathrm{g} \mathrm{mL}^{-1}$ for method A, 7.5-37.5 $\mu \mathrm{g} \mathrm{mL}^{-1}$ for method B and $5-25 \mu \mathrm{g} \mathrm{mL}^{-1}$ for method C. For more accurate results, ringbom optimum concentration ranges are 5-18 $\mu \mathrm{g}$ $\mathrm{mL}^{-1}$ for method $\mathrm{A}$, 8.5-35.5 $\mu \mathrm{g} \mathrm{mL}^{-1}$ for method $\mathrm{B}$ and $6.0-23.0 \mu \mathrm{g} \mathrm{mL}^{-1}$ for method C. The molar absorptivities are $3.55 \times 10^{4}, 2.10 \times 10^{4}$ and $3.10 \times 10^{4} \mathrm{~L}$ $\mathrm{mol}^{-1} \mathrm{~cm}^{-1}$. Where as sandell sensitivities are $0.024,0.041$ and $0.028 \mu \mathrm{g} \mathrm{cm}^{-2}$ for method A, B and C respectively. The mean percentage recoveries are 99.95 for method A, 101.35 for method B and 100.33 for method C. The developed methods were applied for the determination of PST in bulk powder and in the pharmaceutical formulations without any interference from tablet excipients.
\end{abstract}

Keywords: Pitavastatin calcium, $o$-phenanthroline, 2, 2' bipyridyl, Potassium ferricyanide, Spectrophotometry. 


\section{Introduction}

Pitavastatin calcium (PST) is an anti hyperlipidimic agent and is chemically known as calcium (E, 3R, 5S) -7-[2-cyclopropyl-4-(-flurophenyl) quinolin-3-yl]-3, 5-dihydroxyhept-6-enoate, whose structure is given in Fig.1. It acts by inhibiting the enzyme 3-hydroxy-3-methyl glutaryl- coenzyme A (HMG-coA) reductase. ${ }^{1-3}$ Literature survey reveals that, one chromatographic method have been reported for the separation of pitavastatin and its optical isomers ${ }^{4}$ and there are no spectrophotometric methods for the quantification of PST in pure drug and in pharmaceutical formulations. Hence the author has made an attempt to develop simple spectrophotometric methods for the estimation of PST in pure drug and in pharmaceutical formulations. The proposed methods are based on the oxidation of drugs by $\mathrm{Fe}^{3+}$ in presence of $o$-phenanthroline or 2,2 ' bipyridyl or potassium ferricyanide. The colored complex formed was measured at 510,530 and $755 \mathrm{~nm}$ for method $\mathrm{A}, \mathrm{B}$ and $\mathrm{C}$ respectively.

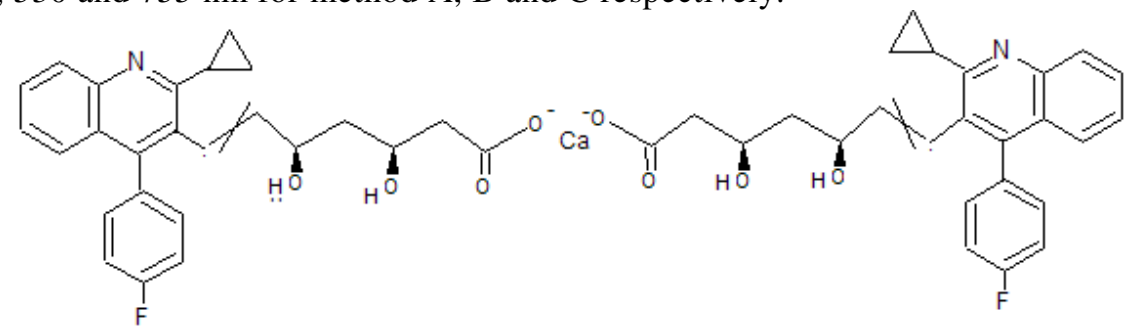

Figure 1. Structure of pitavastatin calcium

\section{Experimental}

\section{Apparatus}

All spectral and absorbance measurements were made on a systronic model 106 digital spectrophotometer with $10 \mathrm{~mm}$ matched quartz cells.

\section{Materials and reagents}

All chemicals used were of analytical reagent grade. PST was obtained from Dr.Reddy's labs Hyderabad. Pitava 1(Zydus Cadila) is the commercial tablet formulation labeled to contain $1 \mathrm{mg}$ of PST per tablet.

$o$-phenanthroline $(0.2 \%)$ was prepared by dissolving $200 \mathrm{mg}$ of $o$-phenanthroline in $100 \mathrm{~mL}$ of distilled water. Ferric chloride $(0.5 \%)$ was freshly prepared by dissolving 500 $\mathrm{mg}$ of ferric chloride in $100 \mathrm{~mL}$ of distilled water. Orthophosphoric acid solution was prepared by mixing $8.5 \mathrm{~mL}$ of orthophosphoric acid with distilled water and final volume make up to $1000 \mathrm{~mL}$. 2, 2' bipyridyl (0.2\%) was prepared by dissolving $200 \mathrm{mg}$ of 2, 2' bipyridyl in $100 \mathrm{~mL}$ of distilled water. Potassium ferricyanide $(0.1 \%)$ was prepared by dissolving $100 \mathrm{mg}$ of potassium ferricyanide in $100 \mathrm{~mL}$ of distilled water.

Stock reference solution $\left(1000 \mu \mathrm{g} \mathrm{mL}^{-1}\right)$ was freshly prepared by dissolving $100 \mathrm{mg}$ of PST in $100 \mathrm{~mL}$ of methanol and then this solution was further diluted with methanol so as to obtain a working standard solution of $200 \mu \mathrm{g} \mathrm{mL}^{-1}$ for method $\mathrm{A}, 150 \mu \mathrm{g} \mathrm{mL} \mathrm{L}^{-1}$ for method $\mathrm{B}$ and $100 \mu \mathrm{g} \mathrm{mL}{ }^{-1}$ for method $\mathrm{C}$. 


\section{General Procedure and Calibration}

In methods $\mathrm{A}$ and $\mathrm{B}$, different aliquots of working standard solution $\left(200 \mu \mathrm{g} \mathrm{mL}^{-1}\right.$ for method $\mathrm{A}$ and $150 \mu \mathrm{g} \mathrm{mL} \mathrm{mL}^{-1}$ for method $\mathrm{B}$ ) from $0.2-1.0 \mathrm{~mL}$ (for method $\mathrm{A}$ ) or $0.5-2.5 \mathrm{~mL}$ (for method B) were transferred in to a series of $10 \mathrm{ml}$ standard flasks. To each flask $1.0 \mathrm{~mL}$ of ferric chloride (for method A) or $1.5 \mathrm{~mL}$ of ferric chloride (for method B) and $1.5 \mathrm{~mL}$ $o$-phenanthroline or 2, 2' bipyridyl were added and kept in a water bath $\left(60 \pm 1^{0} \mathrm{C}\right)$ for 15 $\mathrm{min}$, then immediately cooled to room temperature $\left(25 \pm 1^{0} \mathrm{C}\right)$ using a cold water bath and 1 $\mathrm{mL}$ of $o$-phosphoric acid was added. The solutions were made up to volume with distilled water. The absorbance of each solution was measured at $510 \mathrm{~nm}(\operatorname{method} A)$ or $530 \mathrm{~nm}$ (method B) against the reagent blank. The calibration graph was then prepared by plotting the absorbance versus concentration of the drug. The concentration of the unknown was read from the calibration graph or computed from the regression equation.

In method $\mathrm{C}$, different aliquots of stock reference solution $\left(100 \mu \mathrm{g} \mathrm{mL}^{-1}\right)$ from $0.5-2.5$ $\mathrm{ml}$ were transferred in to a series of $10 \mathrm{ml}$ standard flasks. To each flask $1.5 \mathrm{~mL}$ of ferric chloride and $0.5 \mathrm{~mL}$ potassium ferricyanide were added. The solutions were made up to volume with distilled water. The absorbance of each solution was measured at $755 \mathrm{~nm}$ against the reagent blank. The calibration graph was then prepared by plotting the absorbance versus concentration of the drug. The concentration of the unknown was read from the calibration graph or computed from the regression equation.

\section{Procedure for Tablets}

Thirty tablets were weighed accurately and ground in to a fine powder. An amount of powder equivalent to $25 \mathrm{mg}$ of PST was weighed into a $25 \mathrm{~mL}$ volumetric flask, $10 \mathrm{~mL}$ of the methanol was added and shaken thoroughly for about $10 \mathrm{~min}$, then the volume was made up to the mark with the methanol, mixed well and filtered using a quantitative filter paper. The assay of the tablets was completed according to the general procedure.

\section{Results and Discussion}

Methods A, B and C are based on the oxidation of PST by excess of ferric salt $\left(\mathrm{Fe}^{3+}\right)$ and the reduced state of $\mathrm{Fe}^{3+}$ was utilized besides the unreacted $\mathrm{Fe}^{3+}$. The $\mathrm{Fe}^{2+}$ has tendency to give colored complex on treatment with $o$-phenanthroline ${ }^{5}$ (Scheme 1) or 2, 2' bipyridyl $^{6}$ (Scheme 2) or potassium ferricyanide ${ }^{7}$ (Scheme 3 ).

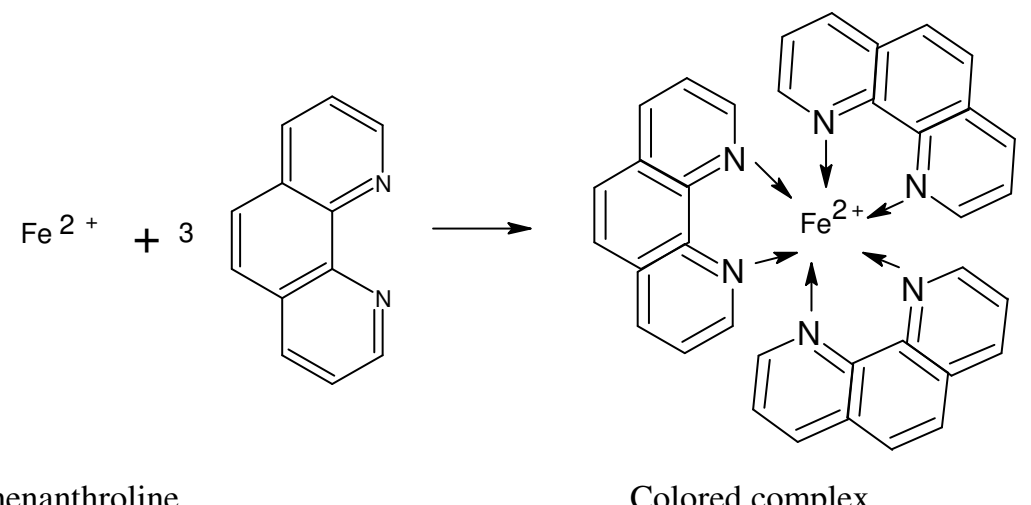

$o$-phenanthroline

Colored complex

Scheme 1.The suggested reaction pathway between $\mathrm{Fe}^{2+}$ and $o$-phenanthroline 


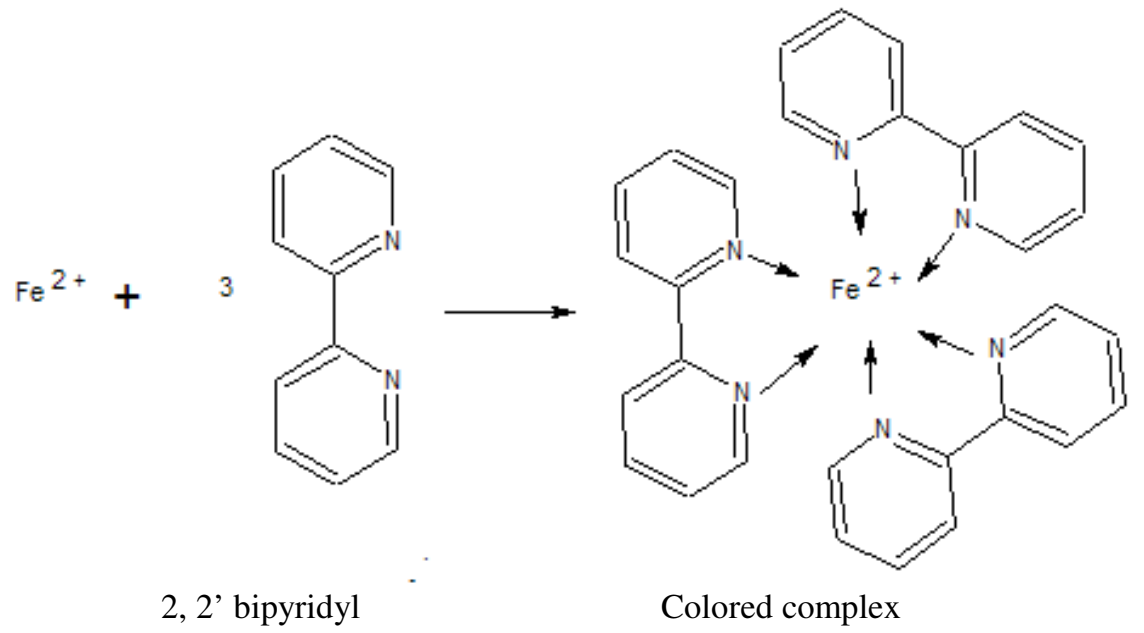

Scheme 2. The suggested reaction pathway between $\mathrm{Fe}^{2+}$ and 2, 2' bipyridyl

$$
3 \mathrm{Fe}^{2+}+\underset{\text { Potassium ferricyanide }}{2\left[\mathrm{Fe}(\mathrm{CN})_{6}\right]^{3-}} \rightarrow \quad \begin{gathered}
\mathrm{Fe}_{3}\left[\mathrm{Fe}(\mathrm{CN})_{6}\right]_{2} \\
\text { colored complex }
\end{gathered}
$$

Scheme 3. The suggested reaction pathway between $\mathrm{Fe}^{2+}$ and potassium ferricyanide

$\mathrm{As}^{3+} \mathrm{e}^{3+}$ interfere even though to a little extent (especially in the lower range of beer's law limits) in the determination of $\mathrm{Fe}^{2+}$ in methods $\mathrm{A}$ and $\mathrm{B}$, the reactivity of the interfering entity $\left(\mathrm{Fe}^{3+}\right)$ has to be made insignificant by complexing it with $o$-phosphoric acid.

\section{Effect of time and temperature}

Three methods were tried on cold and it was found that methods A and B required $2 \mathrm{~h}$ for optimum color development. Method $\mathrm{C}$ needed $5 \mathrm{~min}$ for complete color development. Method A and B needed 15 min heating at $60 \pm 5^{\circ} \mathrm{C}$ on thermostatic water bath for optimum color development. For this reason the heating time was selected to be $15 \mathrm{~min}$ for method A and B. Further increase in the heating time does not cause any change in color intensity, while raising the temperature above $80{ }^{\circ} \mathrm{C}$, the color intensity and the absorbance start to decrease.

\section{Effect of reagent concentration}

The results obtained showed that at least $1.0 \mathrm{~mL}$ of ferric chloride is required for maximum color development in method $\mathrm{A}$ and $\mathrm{C}$ and method $\mathrm{B}$ requires $1.5 \mathrm{~mL}$ of the same. The amount of $o$-phenanthroline, 2,2' bipyridyl and potassium ferricyanide required for optimum color development are 1.5, 1.5 and $0.5 \mathrm{~mL}$ for methods $\mathrm{A}, \mathrm{B}$ and $\mathrm{C}$ respectively. The results obtained are shown in Figs. 2 and 3. The color formed under these conditions in method A and $\mathrm{B}$ was stable for more than $3 \mathrm{~h}$ and in method $\mathrm{C}$ was more than $6 \mathrm{~h}$.

\section{Absorption spectrum and calibration graph}

Absorption spectrum of the colored complexes was scanned in the double beam mode against a reagent blank in the range $400-800 \mathrm{~nm}$. The reaction products show absorption maxima at 510, 530 and $755 \mathrm{~nm}$ for method $\mathrm{A}, \mathrm{B}$ and $\mathrm{C}$ respectively. 
Calibration graphs were obtained according to the above general procedures. The linearity (eight replicates for five different concentrations) was checked by a linear least squares treatment. All the spectral characteristics and the measured or calculated factors and parameters are summarized in Table 1.

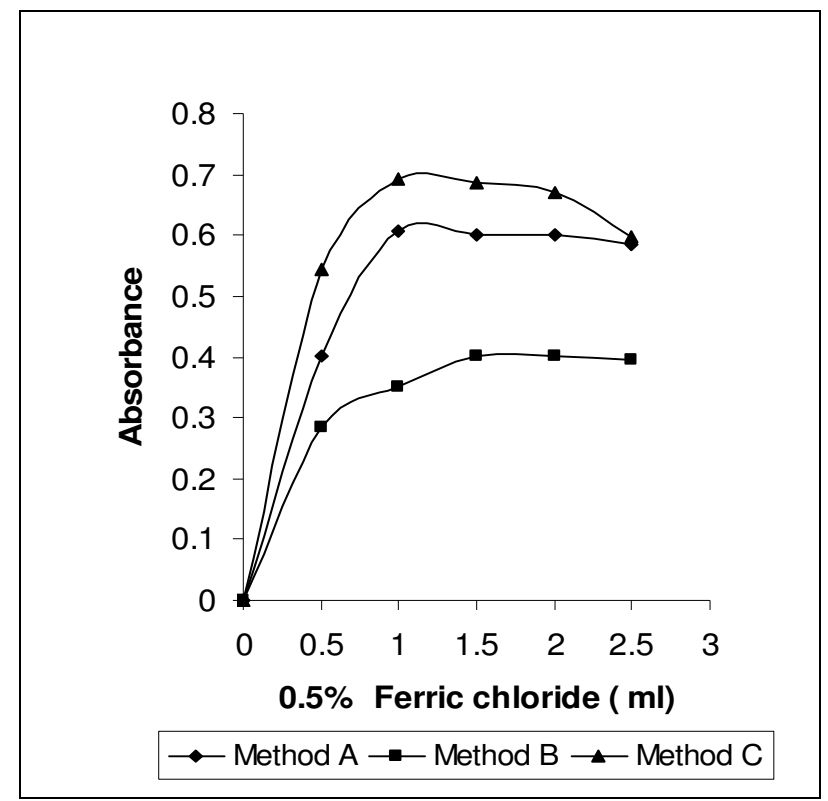

Figure 2. Effect of Ferric chloride concentration $\left(200 \mu \mathrm{g} \mathrm{mL}^{-1}\right.$ drug $+1 \mathrm{~mL}$ of $o$-phenanthroline/2, 2' bipyridyl/ potassium ferricyanide)

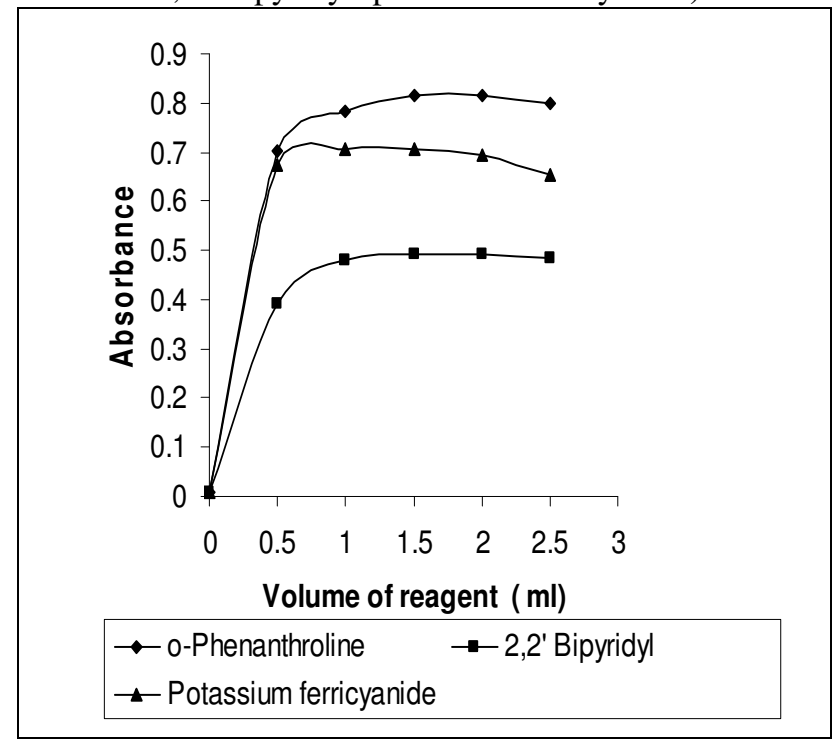

Figure 3. Effect of reagent concentration $\left(200 \mu \mathrm{g} \mathrm{mL}^{-1} \mathrm{drug}+1.0 \mathrm{~mL}\right.$ of ferric chloride for methods $\mathrm{A} \& \mathrm{C}$ and $1.5 \mathrm{~mL}$ for method $\mathrm{B}$ ) 


\section{Sensitivity, Accuracy and Precision}

Sandell sensitivity, molar absorptivity, precision and accuracy were found by performing eight replicate determinations containing $3 / 4^{\text {th }}$ of the amount of the upper beer's law limits. The measured standard deviation (S.D.), Relative standard deviation (RSD), and confidence limits (Table 1) can be considered satisfactory for all the three methods.

Table 1. Optical and Regression Characteristics, Precision and Accuracy of the Proposed Methods for PST

\begin{tabular}{lccc}
\hline \multicolumn{1}{c}{ Parameter } & Method A & Method B & Method C \\
\hline$\lambda_{\max }(\mathrm{nm})$ & 510 & 530 & 755 \\
Beer's law limits $\left(\mu \mathrm{g} \mathrm{mL}^{-1}\right)$ & $4.0-20.0$ & $7.5-37.5$ & $5.0-25.0$ \\
Detection limits $\left(\mu \mathrm{g} \mathrm{mL}^{-1}\right)$ & 0.093 & 0.248 & 0.133 \\
Molar absorptivity $\left(\mathrm{L} \mathrm{mole}^{-1} \mathrm{~cm}^{-1}\right)$ & $3.55 \times 10^{4}$ & $2.10 \times 10^{4}$ & $3.10 \times 10^{4}$ \\
Sandell's sensitivity & 0.024 & 0.041 & 0.028 \\
Optimum photometric range & $5.0-18.0$ & $8.5-35.5$ & $6.0-23.0$ \\
Regression equation $(\mathrm{Y}=\mathrm{a}+\mathrm{bC})$ & & & \\
Slope $(\mathrm{b})$ & $4.0 \times 10^{-2}$ & $2.4 \times 10^{-2}$ & $3.54 \times 10^{-2}$ \\
Standard deviation of slope $\left(\mathrm{S}_{\mathrm{b}}\right)$ & $0.90 \times 10^{-4}$ & $0.80 \times 10^{-4}$ & $1.0 \times 10^{-4}$ \\
Intercept (a) & $3.00 \times 10^{-4}$ & $-2.80 \times 10^{-3}$ & $-8.00 \times 10^{-4}$ \\
Standard deviation of intercept $\left(\mathrm{S}_{\mathrm{a}}\right)$ & $1.26 \times 10^{-3}$ & $1.99 \times 10^{-3}$ & $1.58 \times 10^{-3}$ \\
Standard error of estimation $\left(\mathrm{S}_{\mathrm{e}}\right)$ & $1.20 \times 10^{-3}$ & $1.99 \times 10^{-3}$ & $1.51 \times 10^{-3}$ \\
Correlation coefficient $(\mathrm{r})$ & 0.9999 & 0.9999 & 0.9999 \\
Relative standard deviation $(\%) *$ & 0.219 & 0.182 & 0.169 \\
$\%$ Range of error $($ Confidence & & & \\
0.05 level & 0.183 & 0.153 & 0.141 \\
0.01 level & 0.271 & 0.226 & 0.209 \\
\% Error in bulk samples** & 0.155 & 0.139 & -0.213 \\
\hline
\end{tabular}

*Average of eight determinations

** Average of three determinations

In $\mathrm{Y}=\mathrm{a}+\mathrm{bC}, \mathrm{Y}$ is absorbance and $\mathrm{C}$ is concentration.

\section{Application in pharmaceutical analysis and a statistical comparative study}

The proposed methods (A, B and C) were applied to the spectrophotometric determination of PST in commercial pharmaceutical formulations. The results obtained were compared statistically by the student's t-test and the variance ratio F-test with those obtained by applying the UV spectrophotometric method for PST developed in our laboratory on samples of the same batch and given in Table 2.

The student's t-test values obtained at the $95 \%$ confidence level and five degrees of freedom ${ }^{8}$ did not exceed the theoretical tabulated value of $t=2.57$, indicating no significant difference between the methods compared. The F-value (5.05) also showed that, there is no significant difference between the precision of the proposed methods and the reference method. The proposed methods can be used for routine quality control and analysis of the PST in bulk as well as in their dosage forms. 
Table 2. Results of analysis of tablet formulation containing PST

\begin{tabular}{|c|c|c|c|c|c|c|}
\hline \multirow[t]{2}{*}{ Method } & \multirow{2}{*}{ Formulations } & \multirow{2}{*}{$\begin{array}{c}\text { Labeled } \\
\text { amount } \\
(\mathrm{mg})\end{array}$} & \multicolumn{2}{|c|}{ Recovery $^{\mathrm{a}} \pm$ S.D. $(\%)$} & \multirow{2}{*}{$t^{b}$} & \multirow{2}{*}{$\mathrm{F}^{\mathrm{c}}$} \\
\hline & & & Proposed & Reference $^{\mathrm{d}}$ & & \\
\hline A & Pitava 1 & 1 & $99.95 \pm 0.66$ & & 0.79 & 2.29 \\
\hline B & Pitava 1 & 1 & $101.35 \pm 0.99$ & $100.10 \pm 1.00$ & 1.97 & 1.02 \\
\hline $\mathrm{C}$ & Pitava 1 & 1 & $100.33 \pm 1.69$ & & 2.09 & 2.85 \\
\hline
\end{tabular}

\section{Conclusions}

The proposed methods are simple, accurate and offer advantages of reagent availability and stability, less time consumption and high sensitivity. Although in methods A and B, the color development at room temperature requires $2 \mathrm{~h}$ for completion, this can be shortened to $15 \mathrm{~min}$ by raising the temperature to $60 \pm 5^{0} \mathrm{C}$. The proposed methods are suitable for the determination of PST in pharmaceutical formulations without interference from excipients such as starch and glucose and from common degradation products, suggesting applications in bulk drug analysis.

\section{References}

1. Bolego C, Poli A, Cignarella A, Catapano A L and Paoletti R. Cardiovascular Drugs and Therapy. 2005, 16, 251.

2. Park S, Kang H J, Rim S J, Ha J W, Oh B H, Chung N and Cho S Y. Clinical Therapeutics. 2005, 27, 1074.

3. Saito Y, Yamada N, Teramoto T, Itakura H, Hata Y, Nakaya N, Mabuchi H, Tushima M, Sasaki J, Ogawa N and Goto Y. Atherosclerosis. 2003, 168, 401.

4. Yang Cheng, Fu Xiaotal, Huang, Yuming. Faming Zhunali Shenqing Gongkai Shuomingshu. 2006, 9.

5. Gowri Sankar D, Vamsi Krishna M, Kumar D V S P and Latha P V M, Asian J. Chem. 2005, 17, 1360.

6. Rajendra Kumar J M. High performance liquid chromatography and visible spectrophotometry as tools for the assay of some antibiotics, antipsychotic and antidiabetic agents, Ph.D. Thesis. Andhra University, Visakhapatnam, India, 2003.

7. Reddy M V V N. Studies on high performance liquid chromatographic and visible spectrophotometric methods for quality evaluation of some anti aids and anti cancer drugs, Ph. D. Thesis, Andhra University, Visakhapatnam, India, 2003.

8. Arora P N and Malhan P K, Biostatistics; $1^{\text {st }}$ (eds.). Himalaya publishing house, Mumbai, India 1996, pp 257-323. 


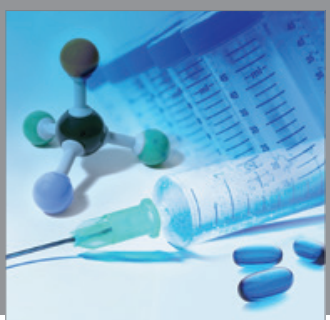

International Journal of

Medicinal Chemistry

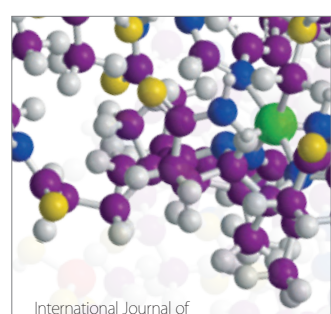

Carbohydrate Chemistry

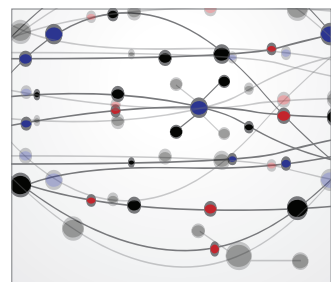

The Scientific World Journal
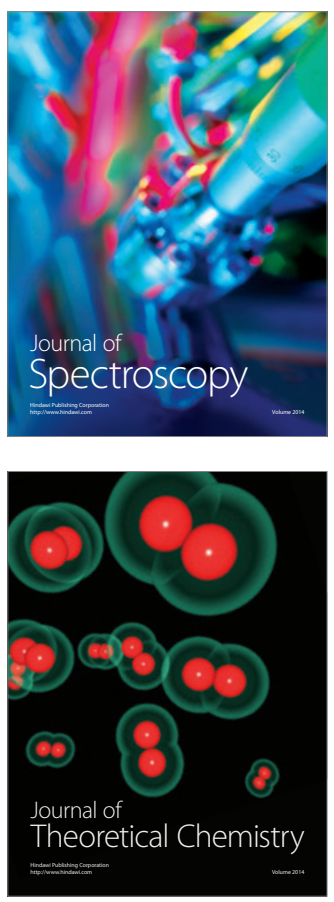
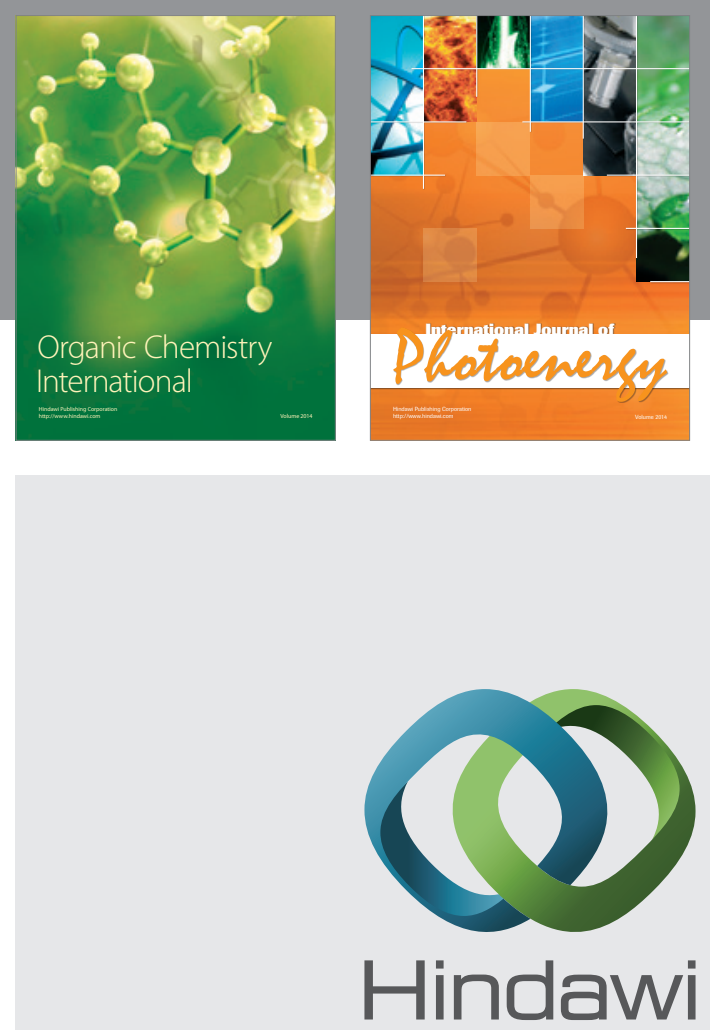

Submit your manuscripts at

http://www.hindawi.com
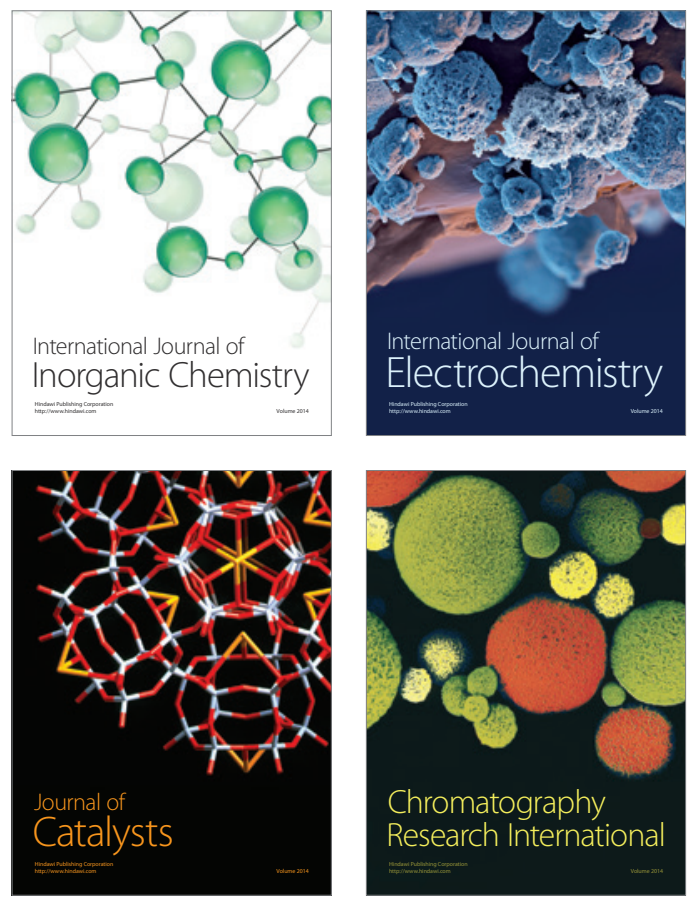
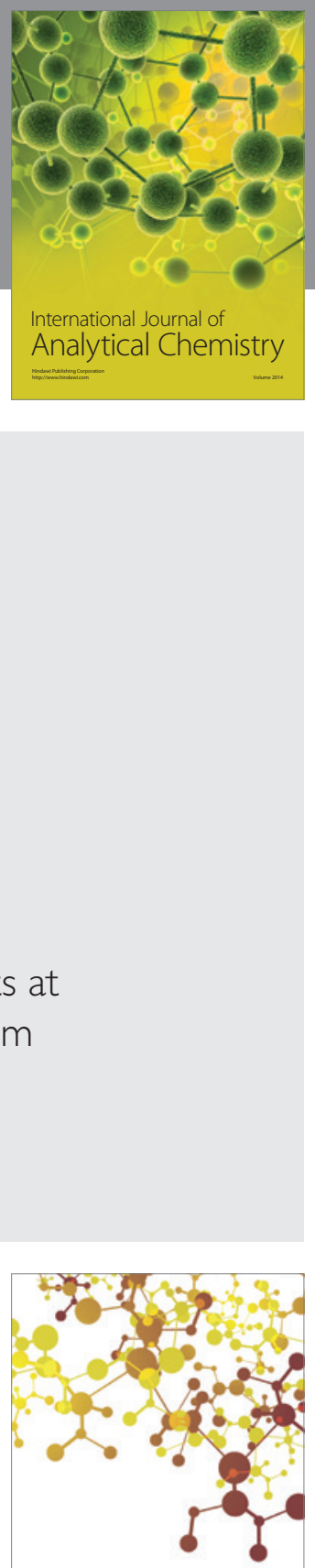

Journal of

Applied Chemistry
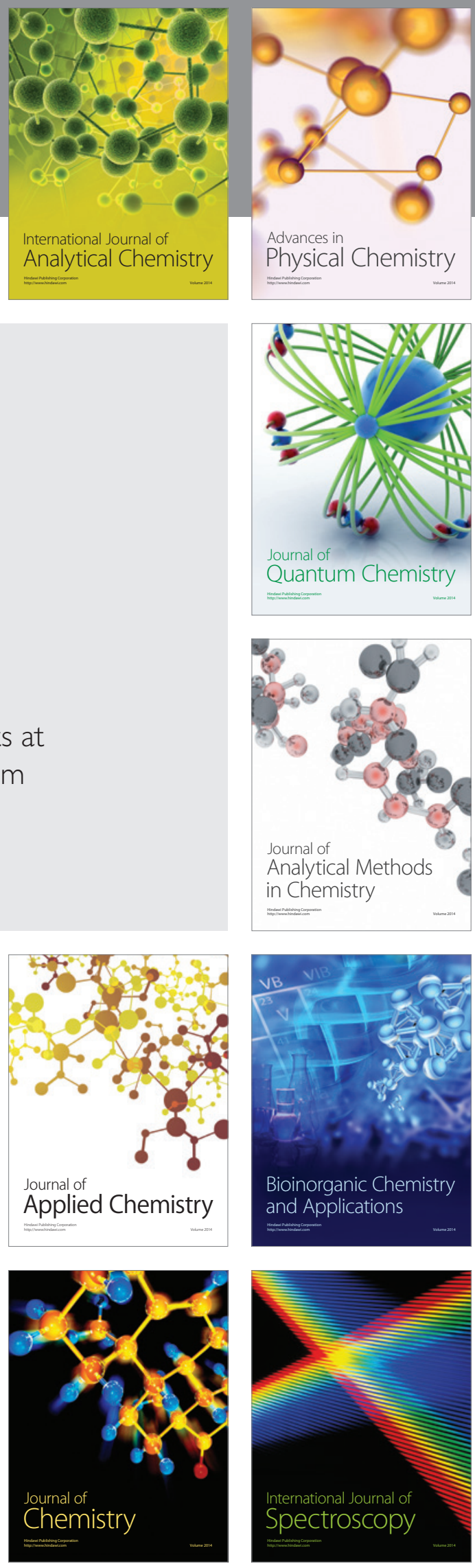